\title{
Troponin I as a mortality marker after lung resection surgery - a prospective cohort study
}

\author{
Ricardo B. Uchoa and Bruno Caramelli ${ }^{*}$ (i)
}

\begin{abstract}
Background: Cardiovascular complications associated with thoracic surgery increase morbidity, mortality, and treatment costs. Elevated cardiac troponin level represents a predictor of complications after non-cardiac surgeries, but its role after thoracic surgeries remains undetermined. The objective of this study was to analyze the relationship between troponin I elevation and morbidity and mortality after one year in patients undergoing lung resection surgery.
\end{abstract}

Methods: This prospective cohort study evaluated 151 consecutive patients subjected to elective lung resection procedures using conventional and video-assisted thoracoscopic techniques at a University Hospital in Brazil, from July 2012 to November 2015. Preoperative risk stratification was performed using the scores obtained by the American College of Physicians (ACP) and the Society of Cardiology of the state of São Paulo (EMAPO) scoring systems. Troponin I levels were measured in the immediate postoperative period (POi) and on the first and second postoperative days.

Results: Most patients had a low risk for complications according to the ACP (96.7\%) and EMAPO (82.8\%) scores. Approximately $49 \%$ of the patients exhibited increased troponin I $(\geq 0.16 \mathrm{ng} / \mathrm{ml})$, at least once, and $22(14.6 \%)$ died in one year. Multivariate analysis showed that the elevation of troponin I, on the first postoperative day, correlated with a 12-fold increase in mortality risk within one year (HR 12.02, 95\% Cl: 1.82-79.5; $p=0.01$ ).

Conclusions: In patients undergoing lung resection surgery, with a low risk of complications according to the preoperative evaluation scores, an increase in troponin I levels above $0.16 \mathrm{ng} / \mathrm{ml}$ in the first postoperative period correlated with an increase in mortality within one year.

Keywords: Troponin, Non-cardiac surgery, Thoracic surgery, Cardiovascular complications, Cardiovascular risk, Perioperative care, Preoperative, Acute coronary syndromes, Myocardial infarction

\section{Background}

Complications after major surgery increase the length of hospital stay, hospital costs, and fatality rate $[1,2]$. Cardiovascular complications associated with thoracic surgery are a challenge for physicians, hospitals, and the health system

\footnotetext{
* Correspondence: bcaramel@usp.br

Heart Institute (InCor) do Hospital das Clínicas da Faculdade de Medicina da Universidade de São Paulo, Rua Maestro Elias Lobo 596, São Paulo, SP CEP 01433-000, Brazil
}

because they significantly increase patient morbidity and mortality, as well as costs [3]. The combination of lung and cardiac diseases is common in patients undergoing lung resections. The common origin of diseases, the similarity of symptoms and coexisting diseases, however, hinder the diagnostic accuracy and effective prediction of cardiac risk in this population [4]. Conventional diagnostic exams, such as electrocardiogram (ECG) and creatine kinase

(c) The Author(s). 2020 Open Access This article is licensed under a Creative Commons Attribution 4.0 International License, which permits use, sharing, adaptation, distribution and reproduction in any medium or format, as long as you give appropriate credit to the original author(s) and the source, provide a link to the Creative Commons licence, and indicate if changes were made. The images or other third party material in this article are included in the article's Creative Commons licence, unless indicated otherwise in a credit line to the material. If material is not included in the article's Creative Commons licence and your intended use is not permitted by statutory regulation or exceeds the permitted use, you will need to obtain permission directly from the copyright holder. To view a copy of this licence, visit http://creativecommons.org/licenses/by/4.0/ The Creative Commons Public Domain Dedication waiver (http://creativecommons.org/publicdomain/zero/1.0/) applies to the data made available in this article, unless otherwise stated in a credit line to the data. 
MB (CK-MB) levels, have low sensitivity and specificity in postoperative myocardial infarction in thoracic surgeries [5].

Perioperative myocardial infarction (MI) is the most feared cause of perioperative cardiac complications after non-cardiac surgeries and is associated with a worse prognosis. However, perioperative MI may not be easily recognized or delayed, as patients do not experience chest pain, probably because most MIs occur during the first days after surgery when they are receiving analgesics [6]. Myocardial injury markers, such as cardiac troponins, have been studied as rapid, available and cost-effective methods to predict cardiovascular events in patients undergoing non-cardiac surgery [7-12]. In this setting, elevated high sensitivity cardiac troponin defines the concept of perioperative myocardial injury (PMI), an increase in cardiac troponin levels in the absence of clinical evidence of myocardial infarction, and strongly associated with mortality within 30 days and one year [13-19].

The objective of this study was to analyze the relationship between the elevation of postoperative troponin I and mortality within one year in patients undergoing lung resection surgery.

\section{Methods}

We included patients undergoing elective lung resection procedures using conventional and video-assisted thoracoscopic techniques in the Hospital de Messejana Dr. Carlos Alberto Studart Gomes in Fortaleza, Ceará State, Brazil, from July 2012 to November 2015. The Comitê de Ética em Pesquisa do hospital de Messejana (local Research Ethics Committee) approved the research protocol on May 16, 2011, under the number CEP 828/11.

\section{Study population and inclusion criteria}

The study population consisted of patients of both genders and of any race who were at least 18 years old. We excluded patients with at least one of the following characteristics: the impossibility of elective surgery, patient refusal, unlikelihood of 1-year follow-up after the surgical procedure, patients without troponin I measurements at the three-time predetermined points and patients with unstable coronary disease.

\section{Study design}

The present study is a prospective cohort study with planned endpoints and analysis. In the preoperative period, we obtained clinical data and surgical risk classification by the Multicenter study of perioperative evaluation for noncardiac surgeries in Brazil (EMAPO) and by the Detsky index of the ACP (American College of Physicians). The scores used in this study are described in detail elsewhere [20, 21].

During the intraoperative period, we monitored patients for complications. A decrease in systolic blood pressure below $90 \mathrm{mmHg}$, a heart rate lower than 60 beats per minute, or the use of vasopressors or inotropes defined hemodynamic instability for this study. Intraoperatively use of bolus was not considered as haemodynamic instability criterion. Intraoperative arrhythmias were ventricular or supraventricular changes that occurred with hemodynamic instability, and that required intervention.

The postoperative management and discharge criteria were those defined in the routine guidelines of the hospital. To measure troponin I, blood samples were collected from all patients during the immediate postoperative period (POi) and the first and second PO. The analyses were performed using the Elecsys 2010 system from Roche ${ }^{\oplus}$, 99th percentile of $0.16 \mathrm{ng} / \mathrm{ml}$, and coefficient of variation $<10 \%$ for values of $0.30 \mathrm{ng} / \mathrm{ml}$. Considering the high specificity of troponin I, we choose an increase in $\mathrm{TnI} \geq 0.16 \mathrm{ng} / \mathrm{ml}$ as the onset of myocardial injury. Patients were evaluated during the period of hospitalization and for 30 days after surgery for the presence of the following complications: acute pulmonary edema, stroke, acute myocardial infarction, cardiac arrest due to ventricular fibrillation, atrial fibrillation with hemodynamic instability, bleeding, pulmonary thromboembolism, respiratory infection, hypotension and death. Mortality within one year was assessed at outpatient visits or by phone call by an investigator blinded to the troponin levels.

\section{Statistical analysis}

For sample size calculation, we considered power of $80 \%$, alpha 0.05 , and estimated mortality rate of 15 and $2.5 \%$ in patients with and without elevated cardiac troponin I. The resulted sample size of our study was 158 patients.

We described the distribution of continuous variables as the mean and standard deviation, and the categorical variables as the relative frequency of the categories. The dependent variable of this study was survival for over one year. The independent variables were origin, gender, aetiology, age, weight, hypertension, coronary disease, diabetes mellitus, smoking habit, smoking load, previous radiotherapy and chemotherapy, functional capacity, surgical risk classification scores, type of surgery, use of video-assisted thoracoscopy, arrhythmia and intraoperative haemodynamic instability, blood transfusion, complications at 30 days and elevation of postoperative troponin I.

The normality of all numerical variables was tested using the Kolmogorov-Smirnov test. Parametric tests and regressive models checked the initial univariate analysis. We constructed Cox univariate regression models for each independent variable, and the outcome was death within one year. The variables that were significantly associated $(p<0.05)$ with the outcome in the univariate analysis were input in a multivariate Cox 
regression model. The statistical program SPSS Inc., version 17.0, was used to perform the calculations.

\section{Results}

\section{Descriptive analysis}

We included 191 patients in the study. In the final analysis, we excluded 40 patients (unable to contact after a follow-up of over one year, troponin $\mathrm{T}$ measured instead of troponin I, and refusal to continue the study).

We depicted the clinical and demographic characteristics of the 151 patients in Table 1. These characteristics show that most of the patients had a low risk of cardiac

Table 1 Baseline clinical and demographic characteristics of the patients

\begin{tabular}{|c|c|c|}
\hline \multirow[t]{2}{*}{ Variable } & \multicolumn{2}{|c|}{ All patients } \\
\hline & $N=151$ & $\%$ \\
\hline \multicolumn{3}{|l|}{ Gender } \\
\hline Male & 58 & 38.4 \\
\hline Mean age (years) & $55 \pm 15$ & \\
\hline Weight (kg) & $63 \pm 12$ & \\
\hline Neoplastic etiology & 116 & 76.8 \\
\hline Hypertension $^{\mathrm{a}}$ & 51 & 33.8 \\
\hline Coronary disease $^{\mathrm{b}}$ & 3 & 2.0 \\
\hline Diabetes mellitus $^{c}$ & 21 & 13.9 \\
\hline Smoking (current + ex-smokers) & 84 & 56 \\
\hline Pack-years & 19 & \pm 25 \\
\hline Previous radiotherapy & 18 & 11.8 \\
\hline Previous chemotherapy & 25 & 16.6 \\
\hline \multicolumn{3}{|l|}{ Functional capacity (MET) } \\
\hline$<4$ MET & 15 & 9.9 \\
\hline$\geq 4 \mathrm{MET}$ & 136 & 90.1 \\
\hline \multicolumn{3}{|l|}{ EMAPO } \\
\hline Low & 125 & 82.8 \\
\hline Moderate & 23 & 15.2 \\
\hline High & 1 & 0.7 \\
\hline Very high & 2 & 1.3 \\
\hline \multicolumn{3}{|l|}{ ACP } \\
\hline Class I & 146 & 96.7 \\
\hline Class II & 5 & 3.3 \\
\hline Class III & 0 & 0 \\
\hline
\end{tabular}

MET Metabolic Equivalent, EMAPO Risk score by the Estudo Multicêntrico de Avaliação Perioperatória (Multicentric Perioperative Evaluation Study), ACP Detsky risk score (American College of Physicians)

${ }^{\text {a} S y s t o l i c ~ b l o o d ~ p r e s s u r e ~ a b o v e ~} 180 \mathrm{mmHg}$ and/or diastolic blood pressure above $110 \mathrm{mmHg}$ and/or patient who reports being hypertensive with or without the use of antihypertensive drugs

${ }^{\mathrm{b}}$ Patients with angina pectoris, previous history of myocardial infarction, or previous surgical and/or percutaneous procedures for myocardial revascularization

'Patients who reported being diabetic with or without the use of medication or those who had a fasting serum glucose level $>126 \mathrm{mg} / \mathrm{dl}$ in preoperative tests complications. In this study, however, $49.7 \%$ of the patients had some degree of PMI, considering that in at least one of the three measurements (immediate PO, $1^{\circ}$ $\mathrm{PO}$, or $\left.2^{\circ} \mathrm{PO}\right)$, the maximum troponin I was higher than or equal to $0.16 \mathrm{ng} / \mathrm{ml}$ Table 2 .

Considering the 2-fold 99th percentile for myocardial infarction recommended by the manufacturer (Roche ${ }^{\circ}$ ) of the kit used in this study, $15.9 \%$ of the patients had a troponin I elevation $\geq 0.32 \mathrm{ng} / \mathrm{ml}$. In contrast, none of these patients met clinical or electrocardiographic criteria for acute myocardial infarction (AMI), according to the fourth universal definition of myocardial infarction [22].

Postoperative complications (up to 30 days) occurred in 21 patients $(13.9 \%)$, and $62.2 \%$ of the complications were of cardiovascular origin (Table 3). Mortality within 30 days was $1.3 \%$, whereas $22(14,6 \%)$ patients died in one year.

\section{Analysis of predictors of mortality within one year}

The univariate analysis of the data showed that troponin elevation $(\geq 0.16 \mathrm{ng} / \mathrm{ml})$ observed at least once during any of the three postoperative periods was significantly

Table 2 Types of surgery and intraoperative and postoperative events of patients included in this study

\begin{tabular}{|c|c|c|}
\hline \multirow[t]{2}{*}{ Variable } & \multicolumn{2}{|c|}{ All patients } \\
\hline & $\mathrm{N}$ & $\%$ \\
\hline Segmentectomy & 58 & 38.4 \\
\hline Lobectomy & 64 & 42.4 \\
\hline Bi-lobectomy & 16 & 10.6 \\
\hline Pneumonectomy & 13 & 8.6 \\
\hline Video-assisted thoracoscopy & 83 & 55.3 \\
\hline Intraoperative arrhythmia ${ }^{a}$ & 16 & 10.6 \\
\hline Intraoperative hemodynamic instability ${ }^{\mathrm{b}}$ & 39 & 25.8 \\
\hline Perioperative blood transfusion & 19 & 12.6 \\
\hline Complications within 30 days $^{c}$ & 21 & 13.9 \\
\hline $\begin{array}{l}\text { Elevation of troponin I }(\geq 0.16 \mathrm{ng} / \mathrm{ml}) \text { in } \\
\text { any of the three measurements }\end{array}$ & 75 & 49.7 \\
\hline Length of surgery (hours) & $3.3 \pm 1.4$ & \\
\hline Length of anesthesia (hours) & $3.8 \pm 1.6$ & \\
\hline Time of ICU stay (days) & $2 \pm 3$ & \\
\hline Time of hospitalization (days) & $8.4 \pm 10.6$ & \\
\hline Death within 30 days & 2 & 1.3 \\
\hline Death within one year & 22 & 14.6 \\
\hline
\end{tabular}

${ }^{a}$ Intraoperative arrhythmias were ventricular or supraventricular changes that occurred with hemodynamic instability, and that required intervention ${ }^{b}$ Haemodynamic instability was defined as a decrease in systolic blood pressure lower than $90 \mathrm{mmHg}$, a heart rate lower than 60 beats per minute, or the use of vasopressors or inotropic drugs (intraoperatively use of bolus was not considered as haemodynamic instability criterion)

'Defined as cardiovascular death, acute myocardial infarction, unstable angina, acute pulmonary edema, cardiogenic shock, arrhythmia with hemodynamic instability, pulmonary thromboembolism, stroke, myocardial infarction, and respiratory infection 
Table 3 Types of postoperative complications within 30 days

\begin{tabular}{ll}
\hline Complications within 30 days & N (\% of total events) \\
\hline AF with hemodynamic instability & $4(19.0)$ \\
Bleeding & $3(14.3)$ \\
Respiratory infection & $4(19.0)$ \\
Hypotension & $5(23.8)$ \\
PT & $2(9.5)$ \\
Stroke & $1(4.8)$ \\
Death due to sepsis & $1(4.8)$ \\
Death due to severe arrhythmia & $1(4.8)$ \\
Acute myocardial infarction & $0(0.0)$ \\
Total & $21(100)$
\end{tabular}

AF Atrial fibrillation, PT Pulmonary thromboembolism

associated with increased mortality within one year. Patients previously classified as very high-risk or highrisk for perioperative cardiac complications by EMAPO had higher mortality within one year compared with the low-risk group. Patients who received prior chemotherapy had higher mortality rates within one year compared with those who did not receive chemotherapy. The length of stay in the ICU and the length of hospital stay showed a significant relationship with mortality within one year. The presence of arrhythmias, intraoperative haemodynamic instability and whether blood transfusions were given intraoperatively were also predictors of mortality within one year (Table 4).

The one-year survival was lower in patients with the highest increases in troponin I $(\geq 0.32 \mathrm{ng} / \mathrm{ml})$ than that in patients with troponin levels $<0.16 \mathrm{ng} / \mathrm{ml}$ in the postoperative period of lung resection surgery (Fig. 1).

The multivariate analysis using a Cox regression model showed that troponin I elevation between 0.16 and $0.32 \mathrm{ng} / \mathrm{ml}$ on the first postoperative day was associated with a 12-fold increase in the risk of death within one year (HR 12.02, 95\% CI: $1.82-79.5 ; p=0.01$ ). For troponin elevations $\geq 0.32 \mathrm{ng} / \mathrm{ml}$, the risk of death within one year was 21 times higher (HR: 21.51; 95\% CI: 1.49$311.55, p=0.02$ ). Other independent predictors of mortality were EMAPO score, which was associated with a high risk (HR: 25.35; 95\% CI: $1.14-563.39 ; p=0.041$ ) and very high risk (HR: 51.85; 95\% CI: 3.3-815.07; $p=$ 0.01 ) and intraoperative blood transfusions (HR: 6.75; 95\% CI: 1.79-25.4; $p=0.005)$ Table 5.

\section{Discussion}

The main finding of this study is that elevation of troponin I in the absence of clinical evidence of myocardial infarction, which characterizes PMI, was a common complication after lung resection surgery, and despite early detection (within the first $48 \mathrm{~h}$ ), it had a prolonged impact. It was significantly associated with increased mortality within one year. This result is consistent with data from previous studies, which show a relationship between troponin I elevation in the immediate postoperative period and increased morbidity and mortality within 30 days and one year in patients undergoing noncardiac surgery [16, 23-27].

There is limited work published in the literature looking specifically to myocardial injury as a marker of outcome at the thoracic surgical population submitted to lung resection. In our study, we collected troponin I from all patients subjected to lung resection, regardless of the preoperative cardiac risk classification, and troponin I levels were analyzed from the limit of detection since we were looking for myocardial injury and not just AMI. Even in a sample in which the vast majority of patients $(96.7 \%$ by ACP and $82.8 \%$ by EMAPO) classified as low cardiovascular risk, the troponin I levels were increased $\geq 0.16 \mathrm{ng} / \mathrm{ml}$ in $49.70 \%$ of patients. This frequency is like that found in surgeries considered high risk, such as vascular and emergency surgeries and represents an important aspect to be addressed in clinical trials with an increased number of patients [28-31].

In thoracic surgery in general, not limited to lung resection, studies have shown different incidences of troponin I elevation in the postoperative period (14-34\%), possibly due to different methodologies used in the studies not designed for prognostic purposes [5, 32-34]. In a recent article, González-Tallada and cols reported the results of an observational study in 177 patients undergoing lung resection surgery. The authors found an incidence of 27, $3 \%$ of myocardial injury after noncardiac surgery (MINS) defined by at least one cardiac troponin elevation with no evidence of a nonischemic etiology. This latter issue characterizes a difference from our study that evaluates an increase in cardiac troponin levels in the absence of clinical evidence of myocardial infarction, i.e., even in the presence of non-cardiac causes but still having an impact in prognosis. This methodological difference can also explain the fact that González-Tellada group didn't find an association of troponin elevation and greater mortality [34].

The elevation in the troponin I level most frequently found in the immediate postoperative period in the present study may represent direct trauma of the cardiomyocytes by thoracic manipulation contiguous to the heart, especially the right ventricle, causing injury, dysfunction) or an overload of pressure and volume. These findings result in an excessive increase in wall tension with secondary cell injury without direct ischaemic complications. This result demonstrates a peculiarity of thoracic surgery with potential importance in clinical practice.

Acute anemia and arterial hypotension, both intraoperatively and postoperatively, is strongly associated with myocardial injury and mortality in non-cardiac surgeries [35-39]. Increased troponin levels have been more 
Table 4 Univariate analysis of perioperative factors and mortality within one year after lung resection surgery

\begin{tabular}{|c|c|c|}
\hline Variables & $\mathrm{HR}(95 \% \mathrm{Cl})$ & $\mathrm{p}$ \\
\hline Aetiology (neoplastic) & $2.96(0.69-12.70)$ & 0.145 \\
\hline Age (years) & $1(0.97-1.03)$ & 0.950 \\
\hline Pack-years & $1(0.98-1.02)$ & 0.948 \\
\hline \multicolumn{3}{|l|}{ Surgery } \\
\hline Segmentectomy & (Reference) & \\
\hline Lobectomy & $0.43(0.13-1.44)$ & 0.173 \\
\hline Bi-lobectomy & $3.15(1.09-9.07)$ & $0.034^{*}$ \\
\hline Pneumonectomy & $1.73(0.46-6.54)$ & 0.416 \\
\hline Video-assisted thoracoscopy technique & $0.48(0.2-1.16)$ & 0.103 \\
\hline Hypertension & $1.24(0.52-3)$ & 0.628 \\
\hline Coronary artery disease & $3.18(0.43-23.73)$ & 0.259 \\
\hline Diabetes mellitus & $1.01(0.3-3.42)$ & 0.992 \\
\hline Previous radiotherapy & $1.69(0.57-5.03)$ & 0.345 \\
\hline Previous chemotherapy & $2.56(1.03-6.33)$ & $0.043^{*}$ \\
\hline \multicolumn{3}{|l|}{ Metabolic equivalence (MET) } \\
\hline$<4$ & $2.17(0.73-6.41)$ & 0.162 \\
\hline$\geq 4$ & (Reference) & 0.858 \\
\hline Time of surgery & $1.14(0.86-1.51)$ & 0.353 \\
\hline Length of hospital stay & $1.02(1-1.04)$ & $0.015^{*}$ \\
\hline Length of ICU stay & $1.17(1.08-1.26)$ & $<0.001^{*}$ \\
\hline \multicolumn{3}{|l|}{ EMAPO score } \\
\hline \multicolumn{3}{|l|}{ Low $(<5)$ (reference) } \\
\hline Moderate (6-10) & $1.11(0.32-3.82)$ & 0.872 \\
\hline High (11 to 15$)$ & $19.07(2.36-153.93)$ & $0.006^{*}$ \\
\hline Very high (> 15) & $12.88(2.85-58.22)$ & $0.001^{*}$ \\
\hline ACP score & $0.61(0.08-4.56)$ & 0.632 \\
\hline Intraoperative arrhythmias & $3.97(1.54-10.25)$ & $0.004^{*}$ \\
\hline Intraoperative haemodynamic changes & $3.63(1.54-8.55)$ & $0.003^{*}$ \\
\hline Intraoperative blood transfusion & $3.29(1.28-8.49)$ & $0.026^{*}$ \\
\hline \multicolumn{3}{|c|}{ Troponin level in the immediate postoperative period (D1) } \\
\hline$<0.16 \mathrm{ng} / \mathrm{ml}$ & (Reference) & \\
\hline $0.16-0.31 \mathrm{ng} / \mathrm{ml}$ & $2.19(0.8-6.05)$ & 0.129 \\
\hline$\geq 0.32 \mathrm{ng} / \mathrm{ml}$ & $5.15(1.73-15.33)$ & $0.003^{*}$ \\
\hline \multicolumn{3}{|l|}{ Troponin in 1st PO (D2) } \\
\hline$<0.16 \mathrm{ng} / \mathrm{ml}$ & (Reference) & \\
\hline $0.16-0.31 \mathrm{ng} / \mathrm{ml}$ & $2.92(1.06-8.05)$ & $0.039^{*}$ \\
\hline$\geq 0.32 \mathrm{ng} / \mathrm{ml}$ & $8.17(2.74-24.33)$ & $<0.001^{*}$ \\
\hline \multicolumn{3}{|l|}{ Troponin in the 2nd PO (D3) } \\
\hline$<0.16 \mathrm{ng} / \mathrm{ml}$ & (Reference) & \\
\hline $0.16-0.31 \mathrm{ng} / \mathrm{ml}$ & $2.43(0.91-6.54)$ & 0.077 \\
\hline$\geq 0.32 \mathrm{ng} / \mathrm{ml}$ & $6.31(2.11-18.85)$ & $0.001^{*}$ \\
\hline Elevated troponin $(\geq 0.16 \mathrm{ng} / \mathrm{ml})$ for at least 1 day & $4.71(1.58-13.99)$ & $0.005^{*}$ \\
\hline
\end{tabular}




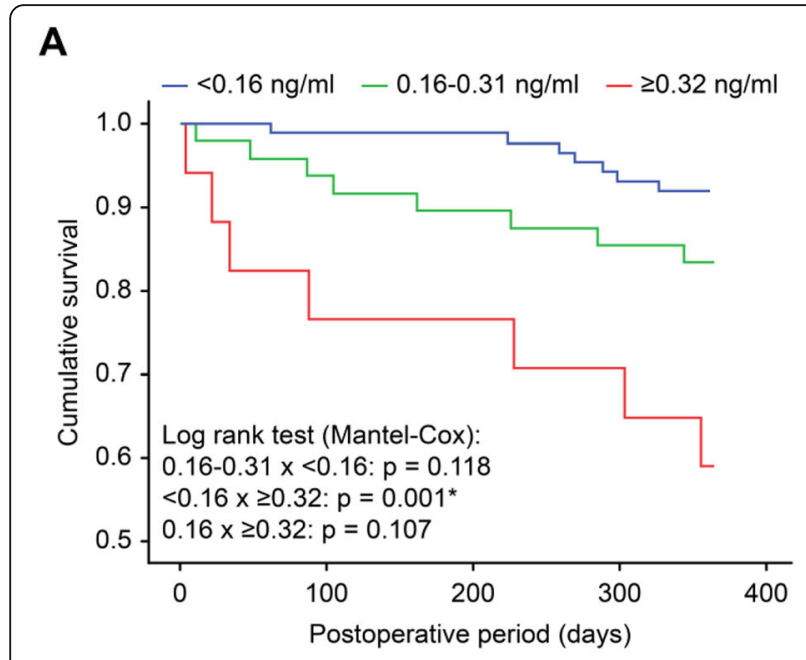

B

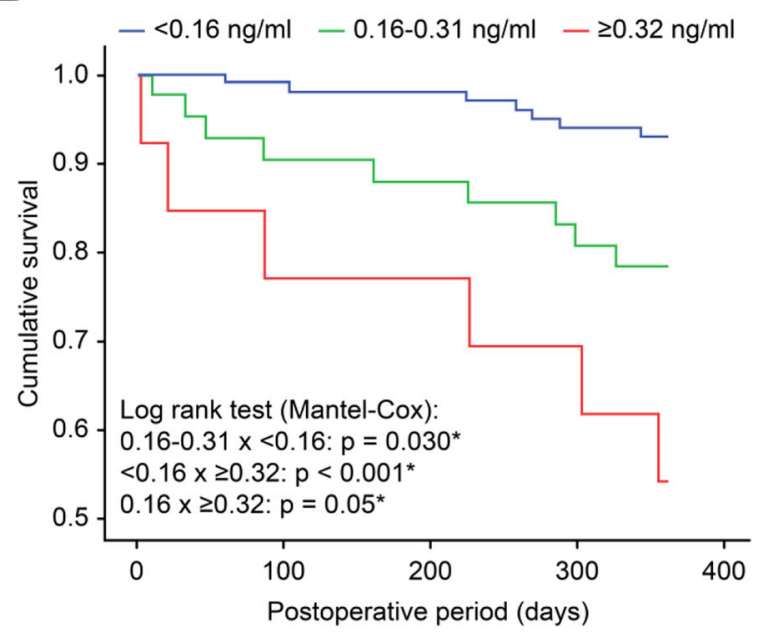

C

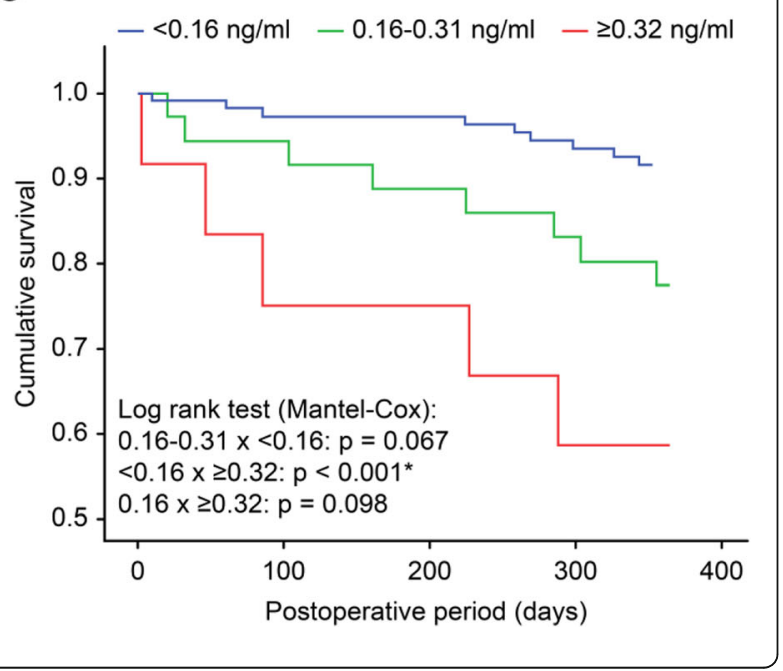

Fig. 1 Survival within one year in patients who had increased troponin I levels during the postoperative period of lung resection surgery according to the time when the elevation was detected: a) Immediate postoperative time, b) First postoperative day, $\mathbf{c}$ ) Second postoperative day. $p=0.05$

prominent in the first hours after surgery and on the first postoperative day, suggesting the importance of the intraoperative period in this outcome.

Mechanisms of tropoin elevation other than myocardial injury are known, but concluding studies are lacking in the perioperative period [40]. In addition to its ability to predict morbidity and mortality, troponin elevation is a warning sign for the occurrence of myocardial injury or underlying conditions (diagnosed or not) that need improvement with new interventions or changes in care.

Table 5 Cox model multivariate analysis of mortality within one year after lung resection surgery

\begin{tabular}{|c|c|c|}
\hline Variables & HR $(95 \%$ Cl) & $\mathrm{p}$ \\
\hline \multicolumn{3}{|l|}{ Surgery } \\
\hline Segmentectomy & (Reference) & \\
\hline Lobectomy & $0.18(0.03-0.95)$ & $0.043^{*}$ \\
\hline Bi-lobectomy & $1.88(0.28-12.39)$ & 0.514 \\
\hline Pneumonectomy & $0.54(0.09-3.34)$ & 0.504 \\
\hline Chemotherapy & $1.38(0.4-4.75)$ & 0.611 \\
\hline $\operatorname{MET}(\leq 4)$ & $0.97(0.18-5.17)$ & 0.971 \\
\hline \multicolumn{3}{|l|}{ EMAPO score } \\
\hline Low $(<5)$ & (Reference) & \\
\hline Moderate (6-10) & $1.47(0.27-8.04)$ & 0.657 \\
\hline High (11 to 15$)$ & $25.35(1.14-563.39)$ & $0.041^{*}$ \\
\hline Very high (> 15) & $51.85(3.3-815.07)$ & $0.005^{*}$ \\
\hline Intraoperative arrhythmias & $3.99(0.73-21.84)$ & 0.111 \\
\hline Neoplastic aetiology & $1.92(0.33-11.11)$ & 0.467 \\
\hline \multicolumn{3}{|l|}{ Troponin D1 } \\
\hline$<0.16$ & (Reference) & \\
\hline $0.16-0.31$ & $0.87(0.11-7.01)$ & 0.897 \\
\hline$\geq 0.32$ & $0.68(0.04-13.17)$ & 0.801 \\
\hline \multicolumn{3}{|l|}{ Troponin D2 } \\
\hline$<0.16$ & (Reference) & \\
\hline $0.16-0.31$ & $12.02(1.82-79.5)$ & $0.010^{*}$ \\
\hline$\geq 0.32$ & $21.51(1.49-311.55)$ & $0.024^{*}$ \\
\hline \multicolumn{3}{|l|}{ Troponin D3 } \\
\hline$<0.16$ & (Reference) & \\
\hline $0.16-0.31$ & $0.56(0.12-2.68)$ & 0.472 \\
\hline$\geq 0.32$ & $0.42(0.04-4.09)$ & 0.456 \\
\hline Intraoperative haemodynamic changes & $2.44(0.7-8.49)$ & 0.16 \\
\hline Blood transfusion & $6.75(1.79-25.4)$ & $0.005^{*}$ \\
\hline
\end{tabular}

*Statistically significant values at $p<0.05$ 
In summary, the present study suggests that cardiac troponin I elevation after thoracic surgery is a marker of increased mortality in one year and could be considered as a routine evaluation in clinical practice for risk stratification purposes. Further studied must address the role of subsequent interventions like coronary risk stratification, drug or interventional treatment options according to the mechanisms involved in the myocardial injury process.

\section{Conclusion}

In a population with mostly a low risk for cardiovascular complications and subjected to lung resection surgery, troponin I level above $0.16 \mathrm{ng} / \mathrm{ml}$ on the first postoperative day are associated with increased mortality within one year. These findings led to the conclusion that in the perioperative period of lung resection surgery, troponin I is a marker of mortality risk, even in patients with low cardiovascular risk, as determined by several scoring systems.

\section{Abbreviations}

MET: Metabolic Equivalent; EMAPO: Risk score by the Estudo Multicêntrico de Avaliação Perioperatória (Multicentric Perioperative Evaluation Study); ACP: Detsky risk score (American College of Physicians); AF: Atrial fibrillation; PT: Pulmonary thromboembolism

\section{Acknowledgements}

Not applicable.

\section{Authors' contributions}

$\mathrm{RBU}$ and $\mathrm{BC}$ equally contributed to the conception and design of the manuscript, acquisition analysis, interpretation of data. RBU and BC drafted the work, revised and approved the final version of the manuscript. RBU and $\mathrm{BC}$ agreed both to be personally accountable for the author's own contributions and to ensure that questions related to the accuracy or integrity of any part of the work, even ones in which the author was not personally involved, are appropriately investigated, resolved, and the resolution documented in the literature. The authors read and approved the final manuscript.

\section{Funding}

Support for the study (lab kits, computer support, Hospital infrastructure) was provided solely from institutional, departmental sources. Bruno Caramelli has an unrestricted personal grant support from National Council for Scientific and Technological Development (CNPq) for Bruno Caramellli. The funding bodies played no role in the design of the study and collection, analysis, and interpretation of data and in writing the manuscript.

\section{Availability of data and materials}

Data from this study is available upon request to corresponding author.

\section{Ethics approval and consent to participate}

The Comitê de Ética em Pesquisa do hospital de Messejana (local Research Ethics Committee) approved the research protocol on May 16, 2011, under the number CEP 828/11. Written consent to participate in the study was obtained from all patients.

\section{Consent for publication}

Not Applicable.

\section{Competing interests}

Both authors have no competing interests for the present study.
Received: 7 January 2020 Accepted: 12 May 2020

Published online: 19 May 2020

\section{References}

1. Khan NA, Quan H, Bugar JM, Lemaire JB, Brant R, Ghali WA. Association of postoperative complications with hospital costs and length of stay in a tertiary care Centre. J Gen Intern Med. 2006;21:177-80,

2. Yu PC, Calderaro D, Gualandro DM, et al. Non-cardiac surgery in developing countries: epidemiological aspects and economical opportunities--the case of Brazil. PLoS One. 2010;5:e10607.

3. Karamichalis JM, Putnam JB, Lambright ES. Cardiovascular complications after lung surgery. Thorac Surg Clin. 2006;16:253-60.

4. Ashley EA, Vagelos RH. Preoperative cardiac evaluation: mechanisms, assessment, and reduction of risk. Thorac Surg Clin. 2005;15:263-75.

5. Lim E, Choy LL, Flaks L, et al. Detected troponin elevation is associated with high early mortality after lung resection for cancer. J Cardiothorac Surg. 2006;1:37.

6. Devereaux PJ, Xavier D, Pogue J, et al. Characteristics and short-term prognosis of perioperative myocardial infarction in patients undergoing noncardiac surgery: a cohort study. Ann Intern Med. 2011;154:523-8.

7. Noordzij PG, van Geffen O, Dijkstra IM, et al. High-sensitive cardiac troponin $T$ measurements in prediction of non-cardiac complications after major abdominal surgery. Br J Anaesth. 2015;114:909-18.

8. Kertai MD, Boersma E, Bax JJ, et al. A meta-analysis comparing the prognostic accuracy of six diagnostic tests for predicting perioperative cardiac risk in patients undergoing major vascular surgery. Heart. 2003;89: 1327-34.

9. Jaffe AS, Ravkilde J, Roberts $R$, et al. It's time for a change to a troponin standard. Circulation. 2000;102:1216-20.

10. Devereaux P, de Beer J, Villar J, Panju A, Berwanger O, Málaga G. Perioperative myocardial infarction: a silent killer. Can J Gen Med. 2006;1:9-11.

11. Maile MD, Jewell ES, Engoren MC. Timing of preoperative troponin elevations and postoperative mortality after noncardiac surgery. Anesth Analg. 2016;123:135-40.

12. Botto F, Alonso-Coello P, Chan MT, et al. Anesthesiology. 2014;120:564-78.

13. Puelacher C, Mueller C. Response by puelacher and mueller to letters regarding article, "perioperative myocardial injury after noncardiac surgery: incidence, mortality, and characterization". Circulation. 2018;138:1077-8.

14. van Waes JA, Grobben RB, Nathoe HM, et al. One-year mortality, causes of death, and cardiac interventions in patients with postoperative myocardial injury. Anesth Analg. 2016;123:29-37.

15. van Waes JA, Nathoe HM, de Graaff JC, et al. Myocardial injury after noncardiac surgery and its association with short-term mortality. Circulation. 2013;127:2264-71

16. Devereaux PJ, Biccard BM, Sigamani A, et al. Association of postoperative high-sensitivity troponin levels with myocardial injury and 30-day mortality among patients undergoing noncardiac surgery. JAMA. 2017;317:1642-51.

17. Reed GW, Horr S, Young L, et al. Associations between cardiac troponin, mechanism of myocardial injury, and long-term mortality after noncardiac vascular surgery. J Am Heart Assoc. 2017;6:e005672.

18. Levy M, Heels-Ansdell D, Hiralal R, et al. Prognostic value of troponin and creatine kinase muscle and brain isoenzyme measurement after noncardiac surgery: a systematic review and meta-analysis. Anesthesiology. 2011;114: 796-806.

19. Ekeloef S, Alamili M, Devereaux PJ, Gogenur I. Troponin elevations after non-cardiac, non-vascular surgery are predictive of major adverse cardiac events and mortality: a systematic review and meta-analysis. Br J Anaesth. 2016;117:559-68.

20. Pinho C, Grandini PC, Gualandro DM, Calderaro D, Monachini M, Caramelli B. Multicenter study of perioperative evaluation for noncardiac surgeries in Brazil (EMAPO). Clinics (Sao Paulo). 2007;62:17-22.

21. Detsky AS, Abrams HB, Mclaughlin JR, et al. Predicting cardiac complications in patients undergoing non-cardiac surgery. J Gen Intern Med. 1986;1:211-9.

22. Thygesen K, Alpert JS, Jaffe AS, et al. Executive group on behalf of the joint European Society of Cardiology (ESC), American College of Cardiology (ACC), American Heart Association (AHA), world heart federation (WHF) task force for the universal definition of myocardial infarction: fourth universal definition of myocardial infarction (2018). Glob Heart. 2018;13:305-38.

23. Bernard A, Deschamps C, Allen MS, et al. Pneumonectomy for malignant disease: factors affecting early morbidity and mortality. J Thorac Cardiovasc Surg. 2001;121:1076-82. 
24. Cohn SL. Preoperative cardiac evaluation of lung resection candidates. Thorac Surg Clin. 2008;18:45-59.

25. Sobol JB, Wunsch H. Triage of high-risk surgical patients for intensive care. Crit Care. 2011;15:217.

26. Biccard BM, Scott DJA, Chan MTV, et al. Myocardial injury after noncardiac surgery (MINS) in vascular surgical patients: a prospective observational cohort study. Ann Surg. 2018;268:357-63.

27. Beattie WS, Karkouti K, Tait G, et al. Use of clinically based troponin underestimates the cardiac injury in non-cardiac surgery: a single-Centre cohort study in 51,701 consecutive patients. Can J Anaesth. 2012;59:1013-22.

28. Lim W, Qushmaq I, Devereaux PJ, et al. Elevated cardiac troponin measurements in critically ill patients. Arch Intern Med. 2006;166(22):2446-54.

29. Landesberg G, Shatz V, Akopnik I, et al. Association of cardiac troponin, CK$\mathrm{MB}$, and postoperative myocardial ischemia with long-term survival after major vascular surgery. J Am Coll Cardiol. 2003;42:1547-54.

30. Bursi F, Babuin L, Barbieri A, et al. Vascular surgery patients: perioperative and long-term risk according to the ACC/AHA guidelines, the additive role of post-operative troponin elevation. Eur Heart J. 2005;26:2448-56.

31. Oscarsson A, Fredrikson M, Sorliden $M$, et al. Predictors of cardiac events in high-risk patients undergoing emergency surgery. Acta Anaesthesiol Scand. 2009;53:986-94.

32. Lucreziotti S, Conforti S, Carletti F, et al. Cardiac troponin-l elevations after thoracic surgery. Incidence and correlations with baseline clinical characteristics, C-reactive protein and perioperative parameters. Rev Esp Cardiol. 2007;60:1159-66.

33. Muley T, Kurz M, Mannle C, et al. Comparison of serum cardiac specific biomarker release after non-cardiac thoracic surgery. Clin Lab. 2011;57:925-32.

34. González-Tallada A, Borrell-Vega J, Coronado C, Morales P, et al. Myocardial injury after noncardiac surgery: incidence, predictive factors, and outcome in high-risk patients undergoing thoracic surgery: an observational study. J Cardiothorac Vasc Anesth. 2020;34:426-32.

35. Carson JL, Duff A, Poses RM, et al. Effect of anaemia and cardiovascular disease on surgical mortality and morbidity. Lancet. 1996;348:1055-60.

36. Chatterjee S, Wetterslev J, Sharma A, Lichstein E, Mukherjee D. Association of blood transfusion with increased mortality in myocardial infarction: a meta-analysis and diversity-adjusted study sequential analysis. JAMA Intern Med. 2013;173:132-9.

37. Valentijn TM, Hoeks SE, Martienus KA, et al. Impact of haemoglobin concentration on cardiovascular outcome after vascular surgery: a retrospective observational cohort study. Eur J Anaesthesiol. 2013;30:664-70.

38. Sessler DI, Khanna AK. Perioperative myocardial injury and the contribution of hypotension. Intensive Care Med. 2018;44:811-22.

39. Hallqvist L, Martensson J, Granath F, Sahlen A, Bell M. Intraoperative hypotension is associated with myocardial damage in noncardiac surgery: an observational study. Eur J Anaesthesiol. 2016;33:450-6.

40. Nagele P. Postoperative hypotension and troponin elevation: association or causation? Br J Anaesth. 2018;120:4-5.

\section{Publisher's Note}

Springer Nature remains neutral with regard to jurisdictional claims in published maps and institutional affiliations.

Ready to submit your research? Choose BMC and benefit from:

- fast, convenient online submission

- thorough peer review by experienced researchers in your field

- rapid publication on acceptance

- support for research data, including large and complex data types

- gold Open Access which fosters wider collaboration and increased citations

- maximum visibility for your research: over $100 \mathrm{M}$ website views per year

At $\mathrm{BMC}$, research is always in progress.

Learn more biomedcentral.com/submissions 